\title{
Cara Memastikan Makanan dan Minuman Tidak Mengandung Babi
}

\section{Patihul Husni}

Departemen Farmasetika dan Teknologi Farmasi, Fakultas Farmasi, Universitas Padjadjaran, Sumedang, 45363 email: patihul.husni@unpad.ac.id

\section{Abstrak :}

Status halal dari makanan dan minuman adalah harga mati bagi seorang muslim. Maraknya kasus makanan dan minuman mengandung babi dan banyaknya produk makanan dan minuman impor mengharuskan seorang muslim untuk waspada dan teliti dalam mengkonsumsi makanan dan minuman yang dijual di pasaran. Oleh karena itu, sangatlah penting bagi seorang muslim mengetahui cara-cara untuk mengecek dan memastikan status halal dari makanan dan minuman yang akan dikonsumsinya sebagai bentuk antisipasi terhadap makanan dan minuman yang tidak halal dan bebas dari kandungan babi.

Keyword : Halal, babi, gelatin

\section{Pendahuluan}

Kehalalan makanan dan minuman adalah sangat penting bagi seorang muslim. Salah satunya produk makanan dan minuman tersebut harus bebas dari kandungan babi. Apalagi banyaknya produk impor yang masuk ke Indonesia mengharuskan seorang muslim untuk waspada dan jeli terhadap produk makanan dan minuman. Selain itu, beberapa saat yang lalu masyarakat Indonesia dihebohkan dengan produk mi instan dan suplemen makanan yang mengandung babi. Berdasarkan hal-hal tersebut maka seorang muslim wajib memastikan makanan dan minuman benar-benar halal dan tidak diragukan status halalnya. Oleh karena itu, seorang muslim harus mengetahui cara-cara untuk mengecek dan memastikan status halal dari makanan dan minuman yang akan dikonsumsi.

\section{Beberapa Cara Untuk Memastikan Makanan dan Minuman Tidak Mengandung Babi}

\section{Cek Logo Halal ${ }^{1}$}

Pastikan pada produk makanan dan minuman terdapat logo halal pada kemasannya. Beberapa produk masih menggunakan logo halal versi Majelis Ulama Indonesia (MUI). Namun mulai tahun 2018 logo halal tersebut berubah menjadi logo halal versi pemerintah yaitu Badan Penyelenggara Jaminan Produk Halal (BPJPH) oleh Kementerian Agama2. Logo halal versi pemerintah akan segera dirilis ${ }^{3}$.

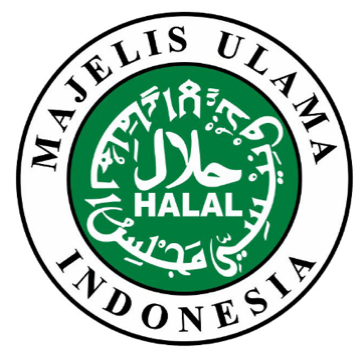

Gambar 1. Logo Halal versi MUI 


\section{Cek Tanda Khusus Mengandung Babi}

Peraturan Kepala Badan Pengawas Obat Dan Makanan Republik Indonesia Nomor 12 Tahun 2016 Tentang Pendaftaran Pangan Olahan pada halaman 54 menyatakan bahwa pangan olahan yang mengandung bahan tertentu yang berasal dari babi harus mencantumkan tanda khusus berupa tulisan "MENGANDUNG BABI" dan gambar babi berwarna merah dalam kotak berwarna merah di atas dasar putih seperti contoh berikut: ${ }^{2}$

\section{MENGANDUNG BABI}

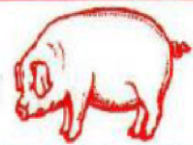

Gambar 2. Tanda Khusus Mengandung Babi

Peraturan Kepala Badan Pengawas Obat Dan Makanan Republik Indonesia Nomor 12 Tahun 2016 tersebut pada halaman 55 juga menyatakan bahwa penulisan bahan pangan yang berasal dari babi harus diikuti dengan kata 'babi'. Contoh : "daging babi", "gelatin babi", "lemak babi" 5

\section{Waspada Produk Mengandung Gelatin}

Cek daftar komposisi pada kemasan makanan dan minuman. Waspadai jika menemukan adanya kandungan gelatin dalam daftar komposisi yang tertera pada kemasan makanan dan minuman tersebut1. Beberapa produk yang mengandung gelatin contohnya coklat, perrnen, cake, dan vitamin. Produk obat, resin, kosmetik dan kapsul juga dapat mengandung gelatin ${ }^{6}$.

\section{Waspada Bahan Pangan Berasal Dari Babi}

Peraturan Kepala Badan Pengawas Obat Dan Makanan Republik Indonesia Nomor 12 Tahun 2016 Tentang Pendaftaran Pangan Olahan pada halaman 55 menyatakan bahwa bahan pangan yang mungkin berasal dari babi antara lain berupa gelatin, enzim, lemak, kolagen, kolostrum, ekstrak darah/marus, hemoglobin terhidrolisat, keratin, ekstrak rambut, plasenta, protein, ekstrak kelenjar timus (thymus extract), hidrolisat timus (thymus hydrolisate), ekstrak usus (stomach extract), bahan penyusun (asam stearat, asam palmitat, gliserol), minyak, ekstrak ginjal, lemak reroti (shortening), pengental, pengemulsi, penstabil, I-sistein, nisin5.

\section{Lakukan Tes Kandungan Babi}

Metode deteksi spesifik spesies untuk penentuan kandungan babi dapat dilakukan menggunakan metode berbasis protein maupun metode berbasis DNA6. Metode berbasis DNA memberikan hasil yang lebih sensitif dan spesifik dibandingkan dengan metode berbasis protein ${ }^{7}$. Salah satu metode yang akurat dan cepat untuk mendeteksi kandungan DNA babi dalam makanan yaitu dengan menggunakan Pork Detection Test atau Porcine Test atau Halal Test yang tersedia dipasaran dimana pengujian kandungan babi terhadap sampel makanan dan minuman sangat mudah dilakukan dan hasil pengujian bisa didapatkan hanya dalam beberapa menit ${ }^{1,7-9}$.

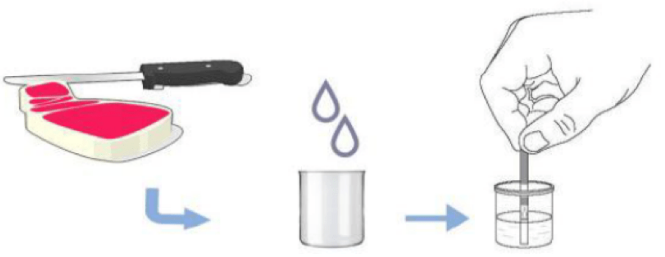




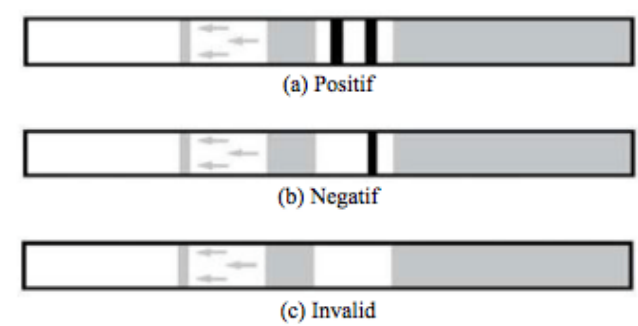

Gambar 4. Interpretasi hasil pengujian menggunakan Pork Detection Test/Porcine Test

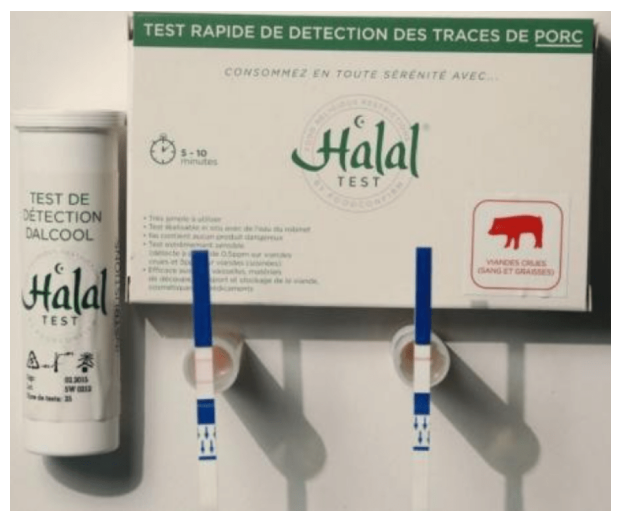

Gambar 5. Tes halal

Cara menggunakan Halal Test yaitu sampel makanan dicampur dengan air hangat di dalam tabung, lalu strip dimasukkan. Hasilnya akan muncul dalam beberapa menit. Satu garis berarti tidak mengandung babi, sedangkan dua garis berarti positif mengandung babi ${ }^{9}$.

\section{Gunakan Aplikasi Untuk Mengetahui Kehalalan Makanan dan Minuman}

Kini deteksi kehalalan produk dapat dicek melalui aplikasi. LPPOM MUI menyediakan fitur "Pencarian Produk Halal" pada laman website-nya ${ }^{10}$. Badan Pengawas Obat dan Makanan (BPOM) juga menyediakan aplikasi bernama Cek BPOM yang juga menyediakan informasi seputar makanan dan obat yang terdaftar di BPOM, serta komposisi yang terkandung didalamnya atau dapat telpon halo BPOM ke 1500533. BPOM juga memiliki website atau laman yang memudahkan masyarakat mengecek produk yang telah dicabut izin edarnya, yaitu http://cekbpom.pom.go.id/. Melalui laman itu, masyarakat bisa memastikan produk, nama produk, dan izin edar ${ }^{11}$.

\section{Kesimpulan:}

Pengetahuan akan cara-cara mengecek dan memastikan status halal dari makanan dan minuman yang akan dikonsumsi merupakan antisipasi terhadap makanan dan minuman yang mengandung babi dan tidak halal.

\section{Daftar pustaka:}

Mengetahui Cara Mendeteksi Kandungan Babi pada Makanan. https://www.aryanto.id/artikel/id/1634/mengetahui-cara-mendeteksi-kandungan-babi-padamakanan [diakses 02 Februari 2018].

BPJPH: Logo Halal MUI tak Berlaku Lagi. http://khazanah.republika.co.id/berita/duniaislam/islam-nusantara/17/10/20/oy3juw396-bpjph-logo-halal-mui-tak-berlaku-lagi [diakses 03 Februari 2018]. 
LPPOM MUI. http://www.halalmui.org/mui14/index.php/main/detil_page/138/24346/30/1 [diakses 03 Februari 2018].

Peraturan Kepala Badan Pengawas Obat Dan Makanan Republik Indonesia Nomor 12 Tahun 2016 Tentang Pendaftaran Pangan Olahan. HIm. 54-55.

Husni, P., Putriana, N.A., dan Wicaksono, I. Metode Deteksi Kandungan Babi dan Alkohol dalam Eksipien Farmasi dan Produk Obat untuk Menjamin Kehalalan Sediaan Obat. Majalah Farmasetika, Vol. 2 No.1:1-7.

Pusat Pengujian Obat dan Makanan Nasional Badan POM. Teknologi Deteksi Berbasis DNA Spesifik Spesies Dalam Autentikasi Produk Halal. INFOPOM. Vol 18 Nomor 1: 3-4. 2017. "Brosur Pork Detection Kit (Porcine Test E Catalogue)". https://ekatalog.lkpp.go.id/backend/produk/download_lampiran/104274 [diakses tanggal 29 Juni 2017] Dengan 'Test Pack' Ini Kandungan Babi dalam Makanan Bisa Dideteksi. https://food.detik.com/info-halal/d-2731805/dengan-test-pack-ini-kandungan-babi-dalammakanan-bisa-dideteksi [diakses 02 Februari 2018]. Pencarian
Produk
Halal.
LPPOM
MUI.

http://www.halalmui.org/mui14/index.php/main/ceklogin_halal/produk_halal_masuk/1 [diakses 04 Februari 2018].

Cek Produk BPOM. http://cekbpom.pom.go.id/ [diakses 4 Februari 2018]. 